\title{
A Transdisciplinary Approach to Identifying Transboundary Tipping Points in a Contentious Area: Experiences from across the Jordan River Region
}

\author{
Juan Miguel Rodriguez Lopez ${ }^{1, * \mathbb{C}}$, Katja Tielbörger ${ }^{2}$, Cornelia Claus ${ }^{2}$, Christiane Fröhlich ${ }^{3}$, \\ Marc Gramberger ${ }^{4}$ and Jürgen Scheffran ${ }^{1}$ (i) \\ 1 Research Group Climate Change and Security (CLISEC), Institute of Geography, Center for Earth System \\ Research and Sustainability (CEN), University of Hamburg, 20144 Hamburg, Germany; \\ juergen.scheffran@uni-hamburg.de \\ 2 Institute of Evolution and Ecology (EvE), University of Tübingen, 72076 Tübingen, Germany; \\ katja.tielboerger@uni-tuebingen.de (K.T.); cornelia.claus@uni-tuebingen.de (C.C.) \\ 3 GIGA German Institute of Global and Area Studies, 20354 Hamburg, Germany; \\ christiane.froehlich@giga-hamburg.de \\ 4 Prospex (Limited Company), 1040 Brussels, Belgium; marc.gramberger@prospex.com \\ * Correspondence: miguel.rodriguez@uni-hamburg.de; Tel.: +49-(040)-42838-9193
}

Received: 23 December 2018; Accepted: 19 February 2019; Published: 23 February 2019

\begin{abstract}
Transdisciplinary research is urgently needed but has rarely been applied in sustainability science. Here, we present a case study for a transdisciplinary approach to identify tipping points in the Jordan River region, an area of severe conflicts and environmental problems. The aim was to identify and prioritize different ecological and social tipping points within a framework of transdisciplinary assessment, using the Jordan River Region as a case study. The methodology included an iterative process in which a multidisciplinary group of scientists and regional stakeholders evaluated emerging tipping points involving professionally facilitated workshops, a correlation analysis, and an anonymous ranking based on specific criteria (practical relevance, scientific novelty, transboundary elements, and feasibility of intervention). During the process, the similarities and differences in the perceptions of the potential case studies by stakeholders from the three countries (Israel, Palestine and Jordan) involved were analyzed. The results found key elements of the term tipping point (abrupt, difficult to predict, irreversible regime shift, difficult management), and showed local and regional differences in evaluating potential case studies, where degradation or desertification of rangelands emerged as a final case study of common concern. The lessons learnt show the potential and challenges of transboundary cooperation, and the possibility of the co-creation of research with stakeholders to build knowledge about the diversity of tipping points. The study concludes that common ground related to the sustainable management of natural resources exists even in highly contentious areas, and among highly different cultural, political, and socio-economic conditions. The approach presented here may thus inform practitioners in prioritizing areas of transboundary sustainability research in other regions.
\end{abstract}

Keywords: tipping points; human-nature interactions; Jordan River; transdisciplinary research; science-stakeholder interaction; transboundary management

\section{Introduction}

Transdisciplinary research aims at developing solutions to real world problems by combining scientific, stakeholder, and traditional knowledge and applying it to social, environmental, and economic problems. In order for such research to succeed, stakeholders and scientists need 
to work together in identifying research questions, producing research results, and disseminating them. The general design of transdisciplinary research has been outlined many times and includes the three steps of co-design, co-conducting, and co-dissemination [1]. Unfortunately, while the need for such an approach to sustainability science has been highlighted, successful applications are still rare. This is regrettable, as many scientific results end up in filing cabinets or in highly specialized scientific publications, instead of informing and supporting practical resource management [2-4]. Including stakeholders up front in designing the research questions and, subsequently, in conducting and disseminating science, is a key lever to gain ownership, which is a prerequisite for the application of the results by decision-makers [5].

Examples for successful transdisciplinary research are needed. Here, we present the Jordan River region, a highly contentious study area with burning environmental issues related to ecological tipping points. If our approach works in such a difficult setting, it can inform transdisciplinary science in other world regions.

Based on previous studies, we started the transdisciplinary process with a working definition of tipping points. We defined tipping points as unexpected, abrupt, and largely irreversible ruptures in the current state of a system caused by small changes in external conditions [6]. In other words, tipping points are characterized by positive feedback loops which result in non-linear dynamics [7]. Much of the literature focuses on conceptual issues around tipping points such as the nature of the pre-tipping point dynamics and early warning systems, or the resilience of systems, i.e., their ability to return to an original state after perturbance $[8,9]$. However, there is still a lack of specific applications and regional case studies addressing irreversible regime shifts and the means in which to avoid them. Examples can be found in research on water management, fishery [10], and climate change effects [11] in the Jordan valley. Although tipping point dynamics have often been studied in ecological systems, the ultimate reasons for such regime shifts are related to societal mechanisms. Often, society and nature interact in tipping points, and thus understanding when and why tipping points emerge is per se a transdisciplinary question. Likewise, tipping points may occur only in society such as the outbreak of violent conflicts.

From a more theoretical view regarding tipping points, the interrelationship between normative human attitudes and environmental systems is far from being understood [12,13] due to the complexity emerging in coupled social-ecological systems including reciprocal effects, feedback loops, and non-linearity [14]. Current research regarding the coupling of human and natural systems has focused mainly on simple mathematical modeling [12,13] or remote-sensing analysis [15]. For example, mathematical models have shown a stabilizing relationship between land composition (e.g., tree-grass dynamics) and the shift in normative attitudes toward an increased protection [16] as the resource becomes scarce. Vice-versa, nature-society interactions could also create negative effects (e.g., tragedy of the commons [14]), leading to regime shifts and the degradation of unregulated common pool resources [17], which could turn into major drivers of tipping processes.

The Jordan River region is an area known for inter- and subnational conflict, but also for cooperation, albeit to a lower degree. Both conflict and cooperation arise from interactions between different actors [18] and thus develop along the same cultural, social, political, and economic pathways. Conflict may also arise around limited natural resources, especially water, i.e., nature and society are closely interrelated. Thus, the question has arisen as to whether there could be areas of concern related to tipping points that apply to all political entities in the region that could serve as a focus for transboundary cooperation. If so, the cooperative management of tipping points could buffer the risk of conflict, highlighting the need to identify such focal areas of concern.

Some theoretical studies in mutualistic networks [6] or grazing systems [19] have suggested a few common properties of systems approaching tipping points, which could be used as early warning indicators, under the premise that effective monitoring is in place to reveal them. These include statistical anomalies such as increased variance and autocorrelation [8,9], which lead to the increased 
sensitivity of the systems to moderate impacts. It has also been shown that saddle points reached during transient dynamics may offer opportunities for reversal by management interventions.

Moreover, results from ecological studies have supported the idea that diversity or complexity begets stability $[20,21]$, but similar studies on social systems are rare [22]. However, the complexity of social-ecological systems (SESs) may also in itself hamper policy-making [23]. One reason is that complexity also increases uncertainty, and cooperative agreements are less likely to be reached when uncertainty exists [24]. In addition, political instability may increase uncertainty and thus also be a trigger for socioeconomic tipping points of their own, e.g., because populations caught up in conflicts are often more vulnerable to climate change [25]. This is an important factor when working in a transboundary setting such as ours. The above highlights the importance of studying conflicts, and vice-versa, the role of cooperation for preventing these sudden regime shifts or tipping points.

The aim of this paper is to analyze the prioritization of different ecological and social tipping points within a framework of transdisciplinary assessment using the Jordan River Region as a case study. In our understanding, a transdisciplinary approach [26] is a prerequisite for achieving science-based resilience of social-ecological systems [27]. Nevertheless, transdisciplinary approaches are still a contested field because of the lack of understanding as to what a transdisciplinary approach should include. Therefore, we adopted the definition of transdisciplinarity as "a critical and self-reflexive research approach that relates societal with scientific problems; it produces new knowledge by integrating different scientific and extra-scientific insights" [26] (p. 8).

Thus, the project CASCADE (Co-Resilience of Natural and Social Systems in a Global Biodiversity Hotspot) began with transdisciplinary approaches to jointly co-design a research agenda among an international and interdisciplinary group of scientists and stakeholders $[28,29]$. The project was guided by the research question of how transdisciplinary cooperation between stakeholders and scientists on social and ecological tipping points as topics of common concern could emerge and be sustained. To that end, we drew on transboundary discussions within a group of interdisciplinary and international scientists and local stakeholders, based on a one-year process of co-designing research for use in a subsequently planned research project. The difficult task of identifying tipping points and of uncovering the complexity of their relationship with normative attitudes and socioeconomic and political factors [12] required a multi-disciplinary consortium of scientists [15,30,31], interconnecting the natural and social sciences [14]. Such an approach has previously been used for analyzing the management options of various landscapes, for example, in rangelands [32], and for building knowledge on climate change adaptation [33].

In the focal region, where cooperation is rare, we assumed that the transboundary management of tipping points was a promising approach to fostering collaboration and mitigating conflict. However, a first challenge related to the transboundary management of tipping points arose because of the complex political situation and the lack of knowledge about these transboundary tipping points. Awareness of the importance of biodiversity and ecosystem functions for human well-being is impeded in the Jordan Valley not only by the long history of violent and non-violent conflicts, but also by a crucial lack of information about the economic consequences of ecosystem degradation [18]. Basic knowledge of the state of ecosystems is lacking, and there is no functioning biodiversity monitoring in Jordan or the West Bank. For these reasons, most of the knowledge about potential tipping points is with the stakeholders of the region. Moreover, knowledge as well as adaptive capacity is unequally distributed in the region. Therefore, transboundary cooperation is mandatory for the timely detection and response to early warning signals pointing towards regionally-relevant regime shifts that are affected by climatic extremes, unsustainable land-use practices, and socio-political conflicts [34].

Another challenge for a co-creation process is that tipping points are a very abstract notion and are often laden with subjective ideas. People might think that they intuitively know what a tipping point is, while in fact, irreversible regime shifts are difficult to distinguish from gradual degradation processes [7]. For this reason, we attempted to develop methods that addressed this problem by using a scientific check of the stakeholder's perception of potential tipping points. This check was achieved 
by means of an iterative process that integrated scientists and stakeholders from many different disciplines and areas of action. Below, we outline the basic stages of this process.

\section{Methods}

\subsection{Study Region}

Our focus was on the Jordan River region (Figure 1), namely Jordan, Palestine, and Israel, an area that combines many desirable attributes for addressing the problem of tipping points, and conflict or cooperation in a SES. It is located in a global biodiversity hotspot [35] including many progenitors of globally important crops [36]. Additionally, the Jordan Valley is the main eastern migration route for European birds, further making the region an area of global conservation concern $[37,38]$. These two aspects combine to make ecological tipping points very important as they could lead to dramatic losses of habitats and important plant and animal species. Steep climate gradients and highly diverse socio-economic settings provide an ideal real-life laboratory for studying a variety of ecological and socio-economic drivers as well as their interactions. At the same time, the region suffers from world-record lows in water and land availability and is characterized by highly vulnerable socio-political conditions that impede adaptive management in an era of change [18]. Resource scarcity will be dramatically aggravated by rapid population growth, and subsequent overexploitation of natural resources $[18,38]$ as well as by climate change $[39,40]$ with more frequent droughts $[41]$. Therefore, the region is not only particularly prone to experience tipping points, but the need for developing pre-emptive management strategies is very high.

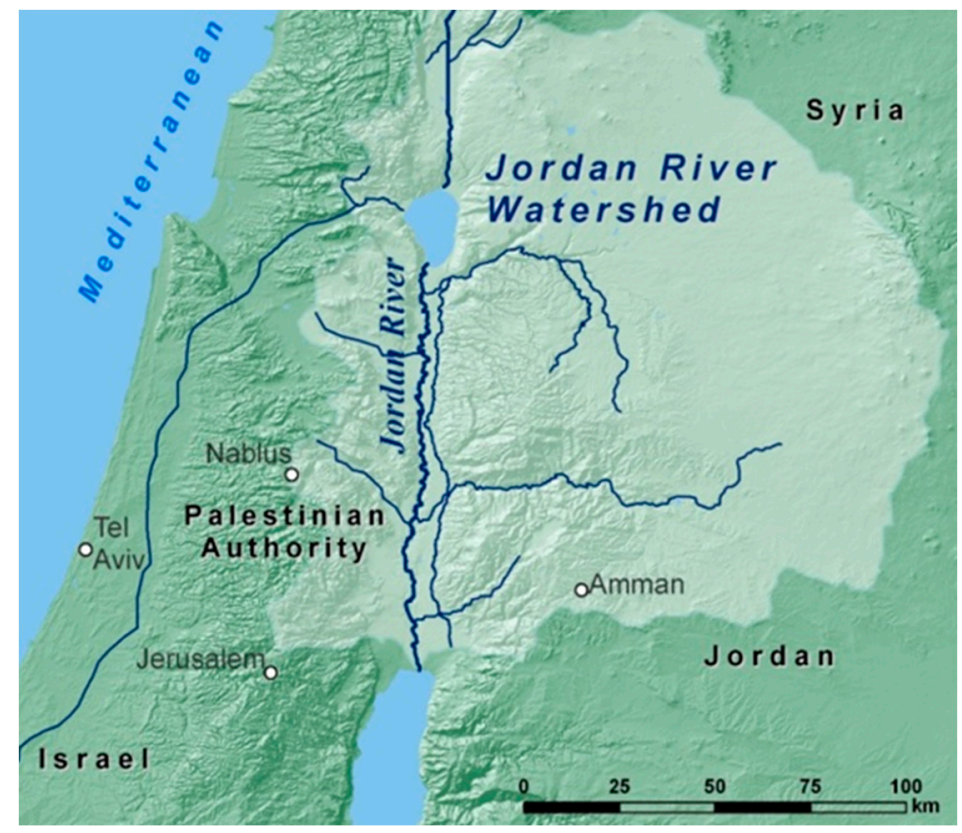

Figure 1. Location map of the Jordan River Region.

\subsection{Stakeholder Analysis and Selection}

Prior to starting the transdisciplinary process, appropriate stakeholders needed to be identified as to who would, on the one hand, be interested in a project about ecological tipping points and, on the other hand, be willing and able to contribute to designing such a project. To that end, we first relied on previous stakeholder analyses in the framework of past research projects in the Jordan River region that have dealt with similar topics [34,37]. This pragmatic approach was taken because the stakeholder analyses were very recent [37], and the resulting stakeholder group was very comprehensive and covered a large range of topics from the environmental sector. Furthermore, the stakeholders in that 
group had already expressed genuine interest in transboundary cooperation and had, via a long-term process [34], built up trust in the coordination team. Finally, the specifics of the funding scheme of this project did not allow for an additional in-depth stakeholder analysis prior to the start. After this pre-selection based on the existing stakeholder group, the need to include several new stakeholders became apparent as the initial group was focused on the issue of water. Therefore, we looked for new stakeholders dealing with relevant issues such as ecosystems, biodiversity, and transboundary cooperation following a snowball method among scientists and stakeholders in the region as well as a focused background stakeholder analysis. As a result, we included stakeholders from each entity who represented e.g., national authorities, associations, and non-governmental organizations (NGOs) dealing with a range of environmental issues like land, agricultural, and water protection as well as the sustainable management of natural resources (see Table 1).

Table 1. Participating stakeholders in the Co-Resilience of Natural and Social Systems in a Global Biodiversity Hotspot (CASCADE) co-design process. " $n$ " refers to the number of participating stakeholders.

\begin{tabular}{|c|c|c|}
\hline Jordan $(n=13)$ & Palestine ( $\mathrm{n}=16$ ) & Israel $(n=12)$ \\
\hline \multicolumn{3}{|c|}{ Governmental Agencies } \\
\hline $\begin{array}{ll}\text { - } & \text { Jordan Valley Authority } \\
\text { - } & \text { Ministry of Agriculture } \\
\text { - } & \text { Ministry of Environment } \\
\text { - } & \text { National Centre for Agricultural } \\
& \text { Research and Extension }\end{array}$ & $\begin{array}{ll}\text { - } & \text { Environmental } \\
\text { - } & \text { Quality Authority } \\
\text { - } & \text { Palestinian } \\
\text { - } & \text { Meteorological Department } \\
\text { Palestinian Water Authority }\end{array}$ & $\begin{array}{ll}\text { - } & \text { Agricultural } \\
& \text { Research Organization } \\
\text { - } & \text { Ministry of } \\
& \text { Environmental Protection } \\
\text { - } & \text { National Park Authority }\end{array}$ \\
\hline \multicolumn{3}{|c|}{ Non-Governmental Organizations (NGOs) } \\
\hline $\begin{array}{ll}\text { - } & \text { Hashemite Fund for Human } \\
\text { Development in Jordan Valley } \\
\text { - } \quad \text { International Union for } \\
\text { Conservation of Nature, Regional } \\
\text { Office for West Asia } \\
\text { - } \quad \text { Jordan Birdwatch Association } \\
\text { - } \quad \text { Royal Botanical Garden } \\
\text { West-Asia-North-Africa Institute }\end{array}$ & $\begin{array}{l}\text { - } \quad \text { House of Palestinian Expertise } \\
\text { - } \quad \text { Palestinian Wildlife Society }\end{array}$ & $\begin{array}{ll}\text { - } & \text { Compassionate conservation } \\
\text { - } & \text { Middle East } \\
\text { - } & \text { HaMaarag-Israel's National } \\
\text { - } & \text { Nature Assessment Program } \\
\text { Open Landscape Institute }\end{array}$ \\
\hline \multicolumn{3}{|c|}{ Scientific Research Institutions } \\
\hline & $\begin{array}{ll}\text { - } & \text { Al-Quds University } \\
\text { An-Najah National University }\end{array}$ & $\begin{array}{ll}\text { - } & \text { Arava Institute for } \\
& \text { Environmental Studies } \\
\text { - } & \text { Ben Gurion University } \\
\text { - } & \text { Tel Aviv University }\end{array}$ \\
\hline \multicolumn{3}{|c|}{ Professional Bodies } \\
\hline & - $\quad$ Palestine Engineer's Association & \\
\hline
\end{tabular}

\subsection{Process Design}

The general approach taken by the consortium was an iterative process of altogether eight workshops which involved either scientists alone (coined 'meetings' in the following) or stakeholders and scientists ('workshops'). Namely, the results generated in a particular workshop were taken up and analyzed in a consecutive meeting, which served to then define the goals of the workshop to come, its content, and the specific methods to reach that goal. Due to these iterations and the interdependency of workshops and meetings, it was difficult to separate the methods and results. Therefore, we present here only the general approach and its chronology and discuss specific interim results and methods derived from them in the Results section.

The process described in this article was a core part of a one-year project design phase of an international inter- and transdisciplinary research project in cooperation between Germany, Jordan, Palestine, and Israel, sponsored by the German Federal Ministry for Education and Research (BMBF). 
The sponsor aimed at funding transdisciplinary projects addressing tipping points in social-ecological systems with a special focus on the loss of biodiversity and ecosystem functions. It is important to note here that due to the source of the funding, the group of scientists consisted mainly of researchers from German universities and research institutions, plus a smaller number of scientists from Jordanian, Palestinian, and Israeli universities who functioned as national coordinators and partly also as gatekeepers to the national stakeholders. This structure contains inbuilt power imbalances between, among others, different nationalities, ethnicities, genders, and age groups. This was carefully and perpetually considered by the neutral process designers before and during the transdisciplinary cooperation to avoid reproducing (neo)colonial structures and discourses.

The process of the co-design of a project idea is presented in a condensed form in Figure 2. In order to guarantee the highest possible degree of neutrality with respect to either specific political or scientific agendas, the process was planned and guided by a team of professional process facilitators.

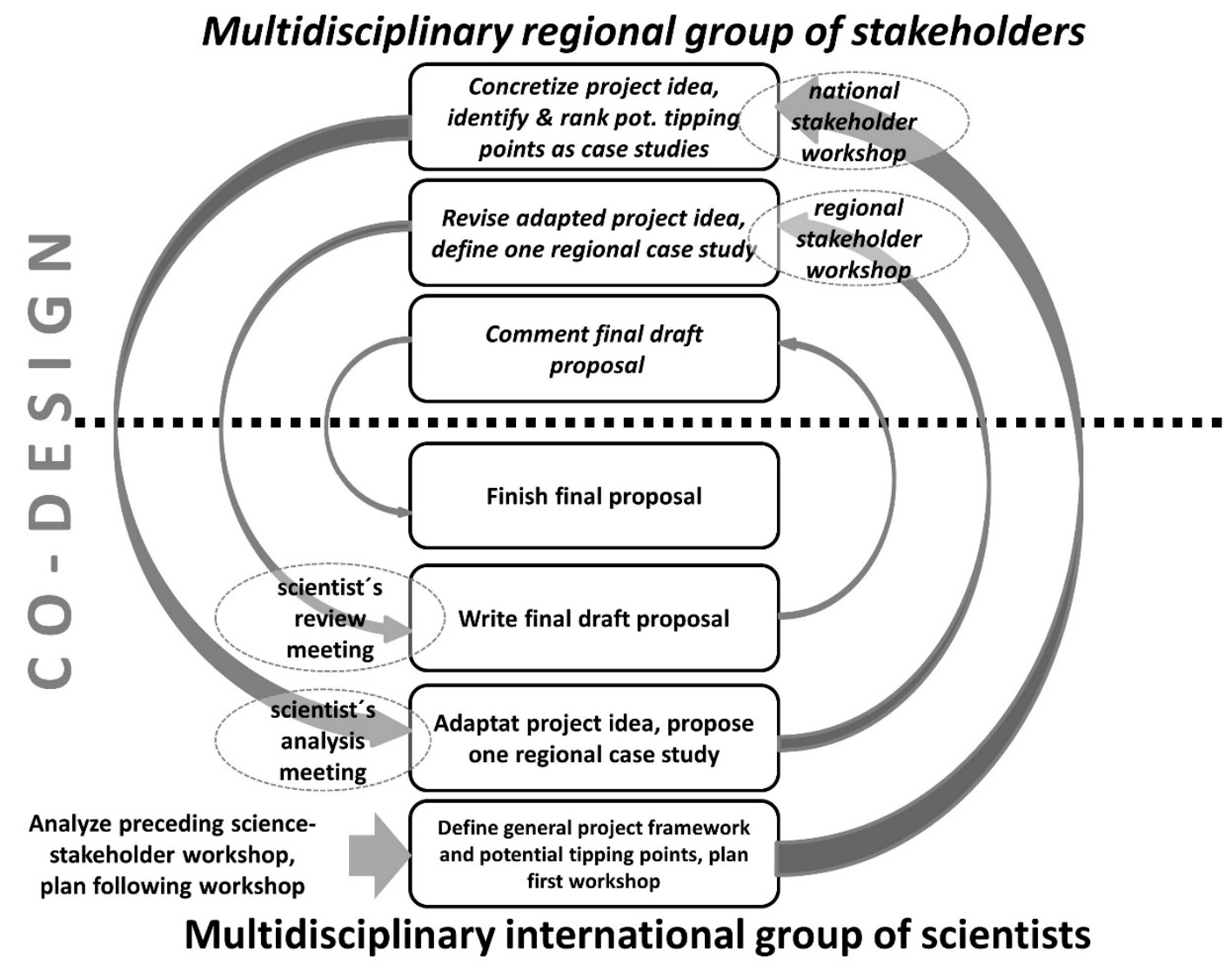

Figure 2. Overview of the co-design process.

Briefly, the process contained a series of scientists' meetings and science-stakeholder workshops which were either multinational or national. The first step was a planning workshop (Figure 2). A series of follow-up meetings and workshops aimed at (a) identifying potential tipping points of concern, (b) prioritizing within and across countries, and (c) designing a research agenda focused on the most important transboundary tipping points identified by the stakeholders.

\section{Results}

Here, we present a detailed account of the process outlined above in chronological order. This includes the interim results, the use of these results to design the consecutive workshop(s), and the final results. 


\subsection{Preparation Meeting}

The first meeting was held in Germany and comprised the German project scientists, the national coordinators, and the professional facilitators. The main goal was to define the main elements of the co-design process, the final list of invited participants (see Section 2.2), and the specific goals and the agenda of the first set of national workshops in the region. After this meeting, the agenda of the first set of workshops was designed.

\subsection{National Workshops in the Region}

Three separate national science-stakeholder workshops were held in the region in a consecutive manner and followed the exact same agenda. Their goal was to obtain an extensive list of possible tipping points of concern including a prioritization assigned by the stakeholders. Additionally, we aimed to identify tipping points that were of high relevance of all three national entities. Each national stakeholder workshop followed the same three steps: (1) defining a common language among the scientists and stakeholders around the issue of tipping points; (2) developing a comprehensive list of potential tipping points of concern for the stakeholders in the region, jointly with the scientists; and (3) creating a ranking of potential case studies according to jointly defined criteria.

The pre-defined criteria included the practical relevance and feasibility of interventions for stakeholders and scientists of all three national entities. Other important ranking criteria for the case studies were scientific novelty and transboundary elements.

The first step aimed to clearly define the notion of tipping points as is currently discussed in the scientific literature to find a common language and use of terms among the scientists and stakeholders. To that end, the following definitions and concepts were discussed with the stakeholders: gradual change vs. tipping points (e.g., what is 'gradual' as opposed to 'sudden' change), reversibility of changes vs. irreversible change, early warning signals, resilience, resistance, threshold-based management (e.g., management to avoid tipping points), and social-ecological systems.

An input presentation on the concept of tipping points was given to the entire group with graphs, examples, and plenty of room for discussion. The main focus was on tipping points in social-ecological systems and associated loss in biodiversity and ecosystem services as this topic had been pre-defined by the call of the funding agency. In the presentation, the concept of tipping points and the dynamics and interactions of social and ecological systems via positive feedback loops were exemplified. This was done using case studies from outside the region (e.g., overfishing) in order to not influence the follow-up process of defining and selecting a case study of concern. Important terms such as resilience vs. resistance, irreversibility, suddenness of change [11,12], or positive feedback loops [6] and downward spirals were a topic of discussion. In the end, it turned out that it was not easy to come to an agreement about what constituted a tipping point, and many initial ideas formulated by the entire group were eventually identified as simple gradual downward projections rather than sudden and irreversible changes. Vice-versa, the dimensions of social tipping points were underestimated by the scientists, i.e., the fact that a gradual change in the natural systems could yield a sudden collapse in society.

Drivers of biodiversity loss that influence the ecological subsystem were discussed including ecosystem fragmentation, habitat loss, invasion of species, pollution, overexploitation of resources, and climate change. The group of scientists elucidated that some drivers may be directly associated with specific social subsystems, e.g., in the case of overexploitation. Others were clear external drivers, like climate change on ecological subsystems or conflict on social subsystems. The result of this discussion was agreement that tipping points occurred when changes in ecosystems exceeded the adaptation potential of both species and the ecosystems themselves. Therefore, it is necessary to identify strategies and management measures that prevent the approach of such critical thresholds and thus curb downward spirals in social-ecological systems. The final key concept of tipping points the group agreed upon was that tipping points were abrupt and difficult to predict, involved an irreversible regime shift, and that their management was challenging. 
After having agreed on common terms and definitions, the second step aimed to start a genuine co-creation process by identifying potential tipping points of concern in a bottom-up strategy. To that end, the stakeholders were first asked to share and document their point of view of potential tipping points in the region by using short and crisp titles. Interestingly, this exercise yielded a wealth of additional information. Namely, instead of producing a simple list of potential tipping points, the stakeholders also started discussing the indicators of regime shifts as well as their drivers. The latter two concepts were discussed and the respective ideas regarding drivers and indicators were noted down for a later stage in the process. The remaining tipping points were then grouped into related topics under comprehensive subheadings to facilitate the identification of common ground among the three national workshops. Such general subheadings included, for example, 'water quality deterioration', 'desertification and degradation of rangelands', or 'invasive species' (see Appendix A for raw data, i.e., the unstructured list of tipping points, drivers, and regime shift indicators).

The next step structured and enriched the discussion of the stakeholders through three potential tipping points that had been identified by the scientists prior to the workshop. These three potential case studies had been pre-selected based on the national strategies with respect to the United Nations (UN) conventions on climate change, desertification and biodiversity as well as on previous stakeholder interactions during the years 2012-2013 [34,37]. The three case studies were: (a) loss of ecosystem functioning caused by drought-afforestation interactions; (b) irreversible rangeland degradation caused by grazing-drought interaction; and (c) species extinctions in invaded arid land caused by grazing-drought interactions. A main and reassuring result was that in all three national workshops, the tipping points identified by the scientists were related to many of the tipping points identified by the stakeholders alone. Therefore, they could be easily included in the main subheadings developed in the preceding exercise. At the end of this step there was a list of potential case studies (tipping points of concern) co-created by the scientists and stakeholders.

The aim of the fourth step was to narrow the case study options down to a single one that could then be addressed by a specific follow-up project. This important step was driven mainly by the stakeholders. Namely, the stakeholders were asked to rank the case studies according to four main criteria: practical relevance, scientific novelty, transboundary elements, and feasibility of intervention. These criteria were discussed with the stakeholders beforehand to identify potential additional criteria of importance. As a consequence, in Palestine and Israel, the stakeholders added two more and rather similar ranking criteria, namely 'local community relevance' and 'social impact'. After finally agreeing on the criteria, each stakeholder had the option of ranking each case study according to each criterion with six scores from 0 to 5, in an anonymous manner. In Amman, 13 stakeholders participated in the ranking exercise, in Ramallah 16, and in Tel Aviv 12.

The result was a list of potential case studies ranked by each stakeholder group according to the different criteria. This was the basis for defining the ideal case study for the project proposal.

\subsection{Analysis and Evaluation Meeting}

After the exercise, the multidisciplinary, international group of scientists including those from the focal region evaluated the three national workshop outcomes. The goal was to identify the most important and relevant case studies which would also comply with the boundary conditions set by the funding agency. In addition, the scientists analyzed the associated social, political, and economic drivers of high relevance in all three stakeholder groups (see Figure 2).

In order to facilitate the comparison among the national entities, we grouped the potential case studies along generic topics. For example, all case studies of each national entity dealing with agriculture in the broadest sense were subsumed under the generic topic "agriculture" (see Table 2 for a list of generic topics). The ranks associated with the generic topics were then summarized for each workshop separately and with respect to the criteria set in the workshops.

The analysis of the ranking was then enriched by enforcing the criterion 'transboundary relevance' with the information available from all three workshops. This was important for the prioritization, 
but could not be fully evaluated by the stakeholders even if it was a direct outcome of the three workshops. However, during the workshops, we deliberately avoided informing the attendants about the outcomes of the other workshops because on the one hand, this would have been possible only for the second and third workshop, and because it was important that each national entity set its own priorities. During the analysis meeting, we thus narrowed down the analysis to those case studies whose generic topic occurred in all three national entities (Table 2). Within these topics, we applied a further ranking based on whether the topics were identified by the stakeholders alone (high priority) or whether they were only added in the second step of the exercise, i.e., added by the scientists (lower priority). For example, afforestation was only pre-identified as a tipping point in Amman, but not so in Ramallah and Tel Aviv, and the topic 'arid land invasion' was not pre-identified in any location, even if it was accepted by all as a potential case study for the ranking exercise.

The next step was then to apply the different ranking criteria and evaluate them for the list of pre-selected 'transboundary tipping points'. After a first visual inspection of the ranking exercise (see Figure 3 for an example of one of the national workshops), it became obvious that the criteria were often not applied independently of each other. Instead, it seemed that the ranking scores of the different criteria were also highly positively correlated, i.e., topics of 'high relevance' for the stakeholders very often scored highly for the other criteria (Figure 3). Due to this finding, we decided to formally test for the degree of correlation among the scores using Spearman correlation analyses. The goal was to evaluate whether applying a single criterion in the ranking procedure would yield the same results as a procedure in which each rank would be factored. The latter procedure would be more complicated and bear the problem of deciding on the weight of each criterion.

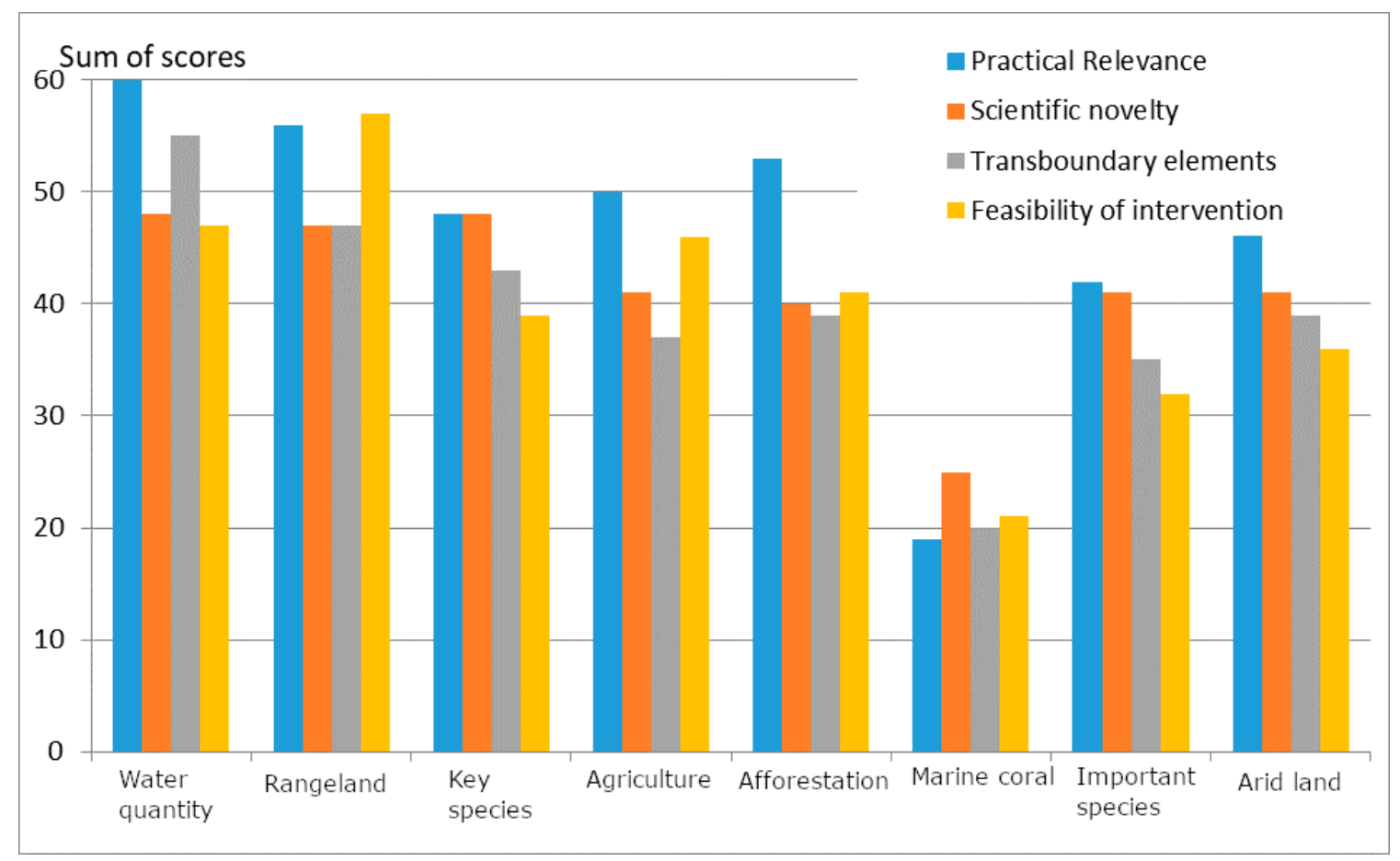

Figure 3. Results of the ranking exercise in the national stakeholder workshop in Amman (the topics are along the x-axis).

After the final analysis of the ranking, a final, rather pragmatic criterion was applied to aid in identifying a potential 'tipping point of highest priority'. This additional criterion was the fit with the call issued by the funding agency. Since this call was addressed to the scientific community, we deemed it appropriate to have the ranking made based on that criterion by the scientists only. For example, 
the call was very explicit in its focus on biodiversity and ecosystem services, i.e., case studies with a low weight on such processes would be ranked lower.

After analyzing the ranking results of the three separate national workshops based on the above sequence of steps, a single case study was selected as the potential focal tipping point to be discussed with the stakeholders in the next step of the co-design process, i.e., the joint workshop. In the following, we outline the separate steps of the ranking procedure in detail.

\subsubsection{Step 1: Identifying Topics of Transboundary Relevance}

As outlined above, we first selected among all of the generic topics those that were developed in all three national workshops (Table 2). The following six were identified in Palestine, Jordan, and Israel and were thus pre-selected as potential topics for a transboundary project. These topics dealt with 'Water Quantity', the degradation of 'Rangeland', tipping points in 'Agriculture', the extinction of 'Key Species', 'Afforestation', and associated tipping points as well as the invasion of 'Arid Land' with non-native shrubs. Of these six topics, 'Afforestation' and 'Arid Land' were added by the group of scientists during the workshops only after the stakeholders had developed their list. Therefore, we assigned these two case studies a lower priority and continued with the ranking procedure using only the first four potential tipping points.

Table 2. Identified potential case studies in the three national stakeholder workshops grouped according to generic topics. The pre-defined case studies from previous stakeholder interactions that were not identified as tipping points by the stakeholders during the first step of the exercise, but were added by the scientists during the workshops, are marked with an asterisk $\left({ }^{*}\right)$.

\begin{tabular}{|c|c|c|c|}
\hline Generic Topic & Jordan & Palestine & Israel \\
\hline Water quantity & Overexploitation of water & $\begin{array}{l}\text { Deterioration of water } \\
\text { quantity }\end{array}$ & Decline of water supply \\
\hline Rangeland & Desertification of rangeland & $\begin{array}{l}\text { Desertification and } \\
\text { degradation of } \\
\text { rangeland }\end{array}$ & Under-/over-grazing \\
\hline Key species & $\begin{array}{c}\text { Extinction of key species such as } \\
\text { Tamarix, Acacia }\end{array}$ & Key species extinction & Key species extinction \\
\hline Agriculture & $\begin{array}{l}\text { Deterioration of soil and food } \\
\text { quality, unsustainable agriculture }\end{array}$ & $\begin{array}{l}\text { Loss of productivity in } \\
\text { agriculture }\end{array}$ & $\begin{array}{l}\text { Agriculture-nature } \\
\text { feedback }\end{array}$ \\
\hline Afforestation & $\begin{array}{l}\text { Ecosystem degradation due to } \\
\text { afforestation with non-native } \\
\text { species }\end{array}$ & $\begin{array}{l}\text { Afforestation with } \\
\text { non-native species * }\end{array}$ & $\begin{array}{l}\text { Afforestation and } \\
\text { droughts in drylands }\end{array}$ \\
\hline Arid land & $\begin{array}{c}\text { Cascading effects via arid land } \\
\text { invasions }\end{array}$ & Arid land invasion * & Arid land invasion * \\
\hline $\begin{array}{l}\text { Important } \\
\text { species }\end{array}$ & $\begin{array}{l}\text { Extinction of } \\
\text { globally/economically important } \\
\text { species: crop wild }\end{array}$ & & \\
\hline Marine corals & Marine coral bleaching & & \\
\hline Water quality & & $\begin{array}{l}\text { Deterioration of water } \\
\text { quality }\end{array}$ & \\
\hline Dead Sea & & Dead Sea degradation & \\
\hline Low values & & Erosion of held values & \\
\hline Pollution & & & Pollution \\
\hline Alien species & & & Alien species \\
\hline Fire & & & Fires \\
\hline Bioregions & & & Shifts in bioregions \\
\hline
\end{tabular}




\subsubsection{Step 2: Ranking According to the Criteria Applied During the Workshops}

In the next step, we analyzed which generic topics scored high with respect to each criterion separately (e.g., Figure 3). The results can be summarized as follows:

- The ranking of the six common generic topics was relatively high in all three locations for the criterion 'practical relevance'. The topics 'Water quantity' and 'Rangeland' received the highest overall rank in all three locations. 'Agriculture' ranked very high in Ramallah and Tel Aviv, and was also among the top five in Amman, but appeared somewhat less important. Instead, 'Afforestation' received very high ranks in Jordan. In general, in Amman and Ramallah, all six common generic topics were considered more practically relevant than in Tel Aviv. In the workshops in Palestine and Jordan, the stakeholders agreed that 'Water quantity' and 'Rangeland' were the most relevant generic topics. In Tel Aviv, the most relevant topic was 'Agriculture', although it had a very small margin compared to 'Rangeland' and 'Water quantity'.

- At all three locations, the stakeholder participants agreed in scoring 'Rangeland', 'Water quantity', and 'Agriculture' as case studies most feasible for intervention.

- The topics 'Water quantity', 'Rangeland' and 'Key species' were also ranked consistently high with respect to transboundary elements. This was a reassuring confirmation of our own selection based on whether or not the topics were raised in all three workshops.

- With respect to the criterion raised in Tel Aviv and Ramallah, i.e., 'Social relevance', 'Water quantity', 'Rangeland', and 'Agriculture' scored highest.

In summary, the generic topics scoring consistently high in all three locations were 'Water quantity', 'Rangeland', and 'Agriculture'. In order to confirm this qualitative result, we then also tested our assumption that the stakeholders did not strongly differentiate between the ranking criteria. As can be seen from visual inspection of the data (Figure 3) and the correlation analyses (Table 3), there was a strong and highly significant correlation among the scores of each criterion. The positive correlations were significant for all three entities, although the correlation coefficients were much larger in Jordan and Palestine than in Israel. Therefore, the ranking could possibly be done by only using a single criterion. Namely, the criterion 'Practical relevance' was sufficient to explain the overall ranking. Ranking by practical relevance led to the same shortlist as above.

Table 3. Spearman correlation coefficient (rho) of the ranking results according to five criteria in all three national entities (All), Jordan (JO), Palestine (PA), and Israel (IL). N(All) = 368, N(JO) $=104$, $\left.\mathrm{N}(\mathrm{PA})=144, \mathrm{~N}(\mathrm{IL})=120 .{ }^{*} p<0.05,{ }^{* *} p<0.01\right)$.

\begin{tabular}{|c|c|c|c|c|c|}
\hline & $\begin{array}{l}\text { Practical } \\
\text { Relevance }\end{array}$ & $\begin{array}{l}\text { Scientific } \\
\text { Novelty }\end{array}$ & $\begin{array}{c}\text { Transboundary } \\
\text { Elements }\end{array}$ & $\begin{array}{l}\text { Feasibility of } \\
\text { Intervention }\end{array}$ & $\begin{array}{c}\text { Local } \\
\text { Community/ } \\
\text { Social Impact }\end{array}$ \\
\hline Practical relevance & 1 & & & & \\
\hline Scientific novelty & $\begin{array}{l}\text { All: } 0.5^{* *} \\
\text { JO: } 0.6^{* *} \\
\text { PA: } 0.7^{* *} \\
\text { IL: } 0.1\end{array}$ & 1 & & & \\
\hline $\begin{array}{l}\text { Transboundary } \\
\text { elements }\end{array}$ & $\begin{array}{l}\text { All: } 0.5^{* *} \\
\text { JO: } 0.6^{* *} \\
\text { PA: } 0.6^{* *} \\
\text { IL: } 0.4^{* *}\end{array}$ & $\begin{array}{l}\text { All: } 0.4^{* *} \\
\text { JO: } 0.6^{* *} \\
\text { PA: } 0.6^{* *} \\
\text { IL: } 0.2^{* *}\end{array}$ & 1 & & \\
\hline $\begin{array}{l}\text { Feasibility of } \\
\text { intervention }\end{array}$ & $\begin{array}{l}\text { All: } 0.6^{* *} \\
\text { JO: } 0.6^{* *} \\
\text { PA: } 0.7^{* *} \\
\text { IL: } 0.5^{* *}\end{array}$ & $\begin{array}{l}\text { All: } 0.4^{* *} \\
\text { JO: } 0.6^{* *} \\
\text { PA: } 0.6^{* *} \\
\text { IL: } 0.0\end{array}$ & $\begin{array}{l}\text { All: } 0.4^{* *} \\
\text { JO: } 0.5^{* *} \\
\text { PA: } 0.5^{* *} \\
\text { IL: } 0.2\end{array}$ & 1 & \\
\hline $\begin{array}{l}\text { Local community / } \\
\text { social impact }\end{array}$ & $\begin{array}{l}\text { PA: } 0.4^{* *} \\
\text { IL: } 0.5^{* *}\end{array}$ & $\begin{array}{l}\text { PA: } 0.3^{* *} \\
\text { IL: } 0.2^{*}\end{array}$ & $\begin{array}{l}\text { PA: } 0.3^{* *} \\
\text { IL: } 0.3^{* *}\end{array}$ & $\begin{array}{l}\text { PA: } 0.4^{* *} \\
\text { IL: } 0.4^{* *}\end{array}$ & 1 \\
\hline
\end{tabular}




\subsubsection{Step 3: Final Selection}

The shortlist of potential topics included 'Water quantity', 'Rangeland' degradation, and tipping points in 'Agriculture'. The final step was then to determine which of them had the best fit with the call of the funding agency. This call highlighted the following issues: the identification of processes which increase the resilience of ecosystems, identifying the processes in the social-ecological system leading to regime shifts, i.e., the degradation of biological systems and the loss of biodiversity, and the means to avoid tipping points and increase resilience in social-ecological systems. The project thus aimed to adopt an integrative approach to examine ecological and social systems, their processes, dynamics, tipping points, and regime shifts with a special focus on the maintenance of biodiversity and the associated ecosystem services.

In order to identify the fit of the three shortlisted topics with the call issued by the funding agency, we looked at the detailed issues suggested under the generic topics during the three workshops:

- The issues stated under the topic 'Water quantity' dealt with water shortage due to water overuse and climate change in all three locations. None of the topics dealt with biodiversity or ecosystem services. Therefore, it appeared that water management was not the ideal case study for this particular call. However, it became clear that water is a very important issue in the region. Furthermore, water is also the main driver of the functioning of the regional ecosystems. Therefore, it made sense to attempt to integrate water issues into the final selection of the topic, even if water quantity per se would not be the focal project.

- The issues stated in the three workshops within the generic topic 'Agriculture' were very heterogeneous. For example, in Amman and Ramallah, the issues stated dealt with specific issues of agricultural management like soil degradation, loss of agricultural productivity, and impact of agrochemicals. In Tel Aviv, the feedback between agricultural and natural systems, i.e., the impact of agriculture on natural systems like loss of habitat was mentioned or, vice-versa, loss of pollination services for agricultural production. Thus, the variety of subjects suggested under this heading made it difficult to select a single tangible case study. Moreover, agricultural management was not the main issue of the call by the funding agency, even if certain aspects such as feedbacks between agricultural and natural systems could be dealt with. Therefore, the theme 'Agriculture' was considered less suitable as a case study.

- The issues stated under the topic 'Rangeland' in all three workshops dealt with desertification and with the degradation or resilience of the semi-natural ecosystem rangeland. At the Amman and Ramallah workshops, overgrazing was identified as the main driver for the degradation of rangeland with climate change accelerating desertification. In Tel Aviv, it was highlighted that degradation may occur either due to over- or under-grazing. As rangelands in the region are the most diverse (semi-) natural ecosystems in the region, we considered this case study as a very good fit with the call of the funding agency.

Taken together, the generic topic 'Degradation of rangelands' with climate change and overgrazing as the main drivers was selected as the 'potential final case study'. Therefore, this topic was elaborated and enriched by elements related to water quantity and prepared for the discussion in the following workshop.

\subsection{Joint Stakeholder Workshop}

A Joint Stakeholder Workshop took place with the main aim to discuss with the stakeholders the steps taken in the preceding analysis meeting. To that end, the results of the three separate workshops were presented to the workshop participants and the results discussed. In the next step, the prioritization process was explained and put up for discussion. Not surprisingly, the stakeholders agreed with the main prioritization based on their own rankings. Additionally, it was understood that while water was a key issue for the region, a project on this topic alone would not be funded. 
Therefore, there was full agreement about the final selection of 'Rangeland degradation' as the final generic topic to be addressed.

After this important step, the process continued with the attempt to develop a specific research agenda around the main topic. To that end, the stakeholders then continued to jointly identify common elements that spanned the range of issues around rangeland degradation. Separate discussion groups were formed around the topics of the drivers and impacts, and about identifying explicit transboundary elements. The latter included both matters of transboundary interest as well as region-wide products that could be generated by a future project. Together with the group of scientists, the key drivers were refined and the means of transboundary management were discussed. These served to enrich the writing of a draft proposal to address science-based management to enhance the resilience of rangelands against tipping points. Work packages were defined that were closely interlinked but addressed the issues of science stakeholder interaction, ecological and hydrological processes, ecosystem services, and conflict development and local management. In addition, the means of stakeholder involvement in co-conducting and co-disseminating the proposed project were discussed. All identified scientific and applied questions were summarized in a final discussion and a first list of research priorities was defined.

\subsection{Analysis Meeting}

The outcome of the Joint Stakeholder Workshop was analyzed by the consortium of scientists in a meeting in Germany. The participants included all scientists from all partner countries as well as the facilitators. Separate groups defined by expertise (e.g., biodiversity, water, economy, ethics, stakeholder involvement) presented their topic-specific results from the workshop and the possible conclusions to be drawn for a follow-up proposal to the whole group. Based on these presentations, work packages were defined. In addition, in-depth work package meetings were utilized to fine-tune methods and approaches and discuss budget requirements. Furthermore, in order to maximize the interdisciplinarity, a timeline was defined for iterative data acquisition and data exchange among the work packages. In addition, each work package refined additional hot topics in their respective science and discussed practical issues such as the location of study areas and follow-up interactions with stakeholders on the ground. After the analysis meeting, the scientists embarked on drafting a proposal based on the results of the co-design process. A first draft proposal was circulated among the stakeholders for final input and comments and the proposal was refined. This process was repeated a second time. The feedback given by the stakeholders ranged from very positive to enthusiastic, enabling the multidisciplinary group of scientists to finalize their concept for future research.

\section{Discussion: Lessons Learnt}

Overall, our transdisciplinary approach was highly successful. During the above co-creation process, we managed to generate a common terminology on the topic of a planned project, and we identified, by means of an iterative process and the application of a structured ranking procedure, a case study for research about tipping points which was of societal relevance, scientific interest, and of transboundary importance.

This is remarkable given the fact that the Jordan River region is known as a contentious area. Nevertheless, interactions between different actors can also lead to cooperation [18]. Specifically, cooperation can appear when systems are approaching tipping points, as has been shown for mutualistic networks [6] and grazing systems [19]. Here, we demonstrated how perceived tipping points regarding water quantity and quality, agricultural land use, and rangelands were emphasized in an equally strong manner in a group of Jordanian, Palestinian, and Israeli stakeholders. This is interesting because previous studies have argued that different socio-economic settings will greatly affect the type of problem that may be prioritized by stakeholders [10]. Nevertheless, stakeholders from three different and often antagonistic states agreed on the practical relevance, scientific novelty, feasibility of intervention, and transboundary character of different tipping points. This indicates 
that transdisciplinary approaches such as ours may facilitate cooperation even in very difficult socio-political settings.

We suggest that three main factors contributed to this success: (1) the fact that the planned project was laid out as a research project in which scientists from the region cooperated; (2) the funding and coordination of the project being handled by a third and neutral party from outside the region (i.e., Germany) which is trusted by all three parties; and (3) the design and facilitation of the co-creation process by professional process designers and facilitators. All of these factors contributed to the fact that stakeholders from the three countries could interact on 'neutral ground'. Thus, the project created a unique platform for discussing burning environmental issues and developing cooperative, transboundary solutions. For example, very specific ideas raised during the workshops were the effective protection of key species via transboundary cooperation, and the development of a shared biodiversity data platform for stakeholders across the region.

Other ideas for cooperation were to establish national-level biodiversity monitoring agencies in Palestine and Jordan, by using an Israeli example as a template. Potentially, effective national monitoring platforms could serve as a starting point for a unified regional system developed from scratch building on the project's results. In Europe, such an attempt was made a posteriori and met with many obstacles in the harmonization of data acquisition [42]. To solve this problem, pan-European initiatives such as EBONE and EU-BON [43] were designed to harmonize national monitoring programs, which made them useful for transboundary decision-making in nature conservation and enabled the analyses of long-term data on natural resources.

The literature about tipping points and transdisciplinary research warns about the difficult task of studying tipping points jointly with stakeholders because of widely varying perceptions of the problem [12]. Instead, it recommends a multi-disciplinary approach $[15,30,31]$ where stakeholders come in only as observers. Our experience confirmed that the development of a common language is key to its success. However, we did manage to agree on common terminology and also increased awareness among the scientists about the important role of diversity in stakeholder interpretations and the need for a common language in transdisciplinary processes. Furthermore, a detailed and in-depth discussion of the notion of 'tipping points' and associated terms (e.g., resilience and resistance, threshold-based management, etc.) was facilitated through a neutral party. It became clear that even the very same specific topic sometimes yielded entirely different interpretations by the stakeholders including justifications of its relevance. For instance, a closer look at agriculture as a topic revealed that this topic included a large variety of aspects that were difficult to separate from each other. Thus, by assigning a lower priority to that topic in the end, we may have missed case studies of interest. For example, subtopics mentioned included the deterioration of soil and food quality and unsustainable agriculture (Jordan), the loss of productivity in agriculture (Palestine), and agriculture-nature feedbacks (Israel). As the discussion progressed (Appendix A), the diversity of responses made it clear that the differences may be the result of disparities in perceptions and real-world problems on the national level. It is thus surprising that many other topics, and especially the priority topic selected in our co-design process, were ranked and discussed in a highly consistent manner across the region.

Previous studies have suggested that a transdisciplinary approach leads to higher quality and durability of the research via ownership of results by the stakeholders [6]. In our case, high levels of participation by local stakeholders supported the success of the decisions made [7] and indicated new potentials for cooperative work [10], thereby laying the groundwork for a future larger project. At the same time, these interactions occurred in a space of asymmetric power relations and in the context of multilayered conflicts of interest. Therefore, we would like to draw attention to a potential dilemma which may be caused by "dysfunctional consensus" resulting from transdisciplinary research [44]. This refers to the fact that the stakeholders' perceptions may be biased or lead to a misallocation of research resources. With this in mind, the case presented here was analyzed with regard to how stakeholders ranked and prioritized the tipping points. They were free to give maximum rankings to 
all topics, i.e., there were no trade-offs due to constrained resources. Thus, we assumed that they made their choices depending on their current interests. These were likely to be affected by the individual socio-economic situation as well as some institutional funding interests. As a result, some degree of "dysfunctional consensus" may have occurred during the ranking of the different tipping points, which illustrates the need for a refined and conscious process of stakeholder selection. However, the large consistency in the interest regarding specific tipping points indicates that the bias may have been relatively small.

\section{Conclusions}

This paper presented the iterative process of identifying a transboundary case study for a transdisciplinary research consortium in a conflict region, namely the Jordan River basin. Over a period of 12 months, a group consisting of an interdisciplinary group of Palestinian, Jordanian, Israeli, and German scientists as well as local stakeholders identified emerging environmental tipping points in the Jordan River basin that were relevant to all actors involved through a series of carefully designed exercises. The results showed local and regional differences in evaluating potential case studies not only in their ranking, but also in the variety of topics that were discussed under the same title. Nevertheless, the degradation or desertification of rangelands emerged as a final case study of common concern due to the high-ranking results, high transboundary relevance, and scientific novelty and opportunity for scientists and stakeholders alike.

Transdisciplinary approaches have been advocated but are still rarely adopted in the field of sustainability research. They have great potential for generating research results which are both scientifically novel as well as helpful for political decision-making. While they raise a host of ethical issues, for instance, the question of power disparities between the researchers and stakeholders or between different nationalities, they also offer a way to bring together rigorous empirical research and local and practical knowledge which can help to develop new approaches to transboundary problems. This is particularly relevant in situations of protracted conflict, as is the case of the Jordan River basin, but it also requires a high level of reflexivity and self-critique from all parties involved. Namely, true transdisciplinarity goes well beyond simply involving local stakeholders as a potential audience or even as the mere object of research. Instead, all actors involved need to meet at eye level and as equals, in order to co-design, co-produce, and co-disseminate the research.

In the professionally moderated transdisciplinary co-design process presented here, the first step was to identify possible research questions regarding desertification, i.e., the degradation of (semi-) natural rangeland, as a key tipping point for the species-rich Jordan River region. In order to achieve this, the transdisciplinary group explored and jointly analyzed the drivers, impacts, and indicators of rangeland degradation, a process that took 12 months and several meetings in different group constellations. The next logical step would be to continue this research with field experiments to explore the tipping points, in particular, the effect of extreme drought and grazing on rangelands. Using these results, we would like to parameterize and validate hydro-ecological models up to the landscape level in collaboration with local users for the social value and ecosystem services of the rangelands to subsequently identify early warning signals for the tipping points.

The lessons learned through this exercise are valuable aspects of this study. First, we showed again that transboundary cooperation in this conflict region is possible, if a common area of interest can be found and if the dialogue is professionally managed [34,37]. Second, the co-creation of research with stakeholders made it possible to build knowledge about the diversity of meanings assigned to different tipping points. Third, we learned about the challenges involved in a transdisciplinary approach. For example, possible bias in the discussion needs to be included as a part of the analysis, as done by using the results of our correlation analysis above. The same is true for a specific, methodological focus on stakeholder selection. Therefore, we have shown that a transdisciplinary approach can make sustainability research stronger by introducing a high level of reflexivity to the scientific process as well as by critically engaging with the relevance of sustainability research for pressing social problems. 
Author Contributions: J.M.R.L. wrote the original draft and all other authors contributed considerably to the revisions. C.C. analyzed the data and K.T. conceived the idea for the study. C.F. contributed expertise on conflict and cooperation in the Jordan basin and a post/de-colonial research perspective. J.S. contributed to the concept of tipping points. M.G. led the design and facilitation of the stakeholder process with his colleagues from Prospex.

Funding: This research was supported by the German Federal Ministry of Education and Research (BMBF) with the Grant "Tipping points, dynamics and interactions of social and ecological systems (BioTip)" and by the Cluster of Excellence "Climate, Climatic Change and Society" (CliCCS) funded through the German Science Foundation (DFG).

Acknowledgments: We are indebted to the regional coordinators A. Jayyousi, A. Salman, E. Karablieh, and R. Twite for their heavy engagement in the entire co-design process and for being the main contacts for the regional stakeholders. We specifically thank all participating stakeholders and the scientists from the region for their active engagement. We also thank two anonymous reviewers for their helpful comments. Meike Schickhoff collaborated as a student assistant.

Conflicts of Interest: The authors declare no conflict of interest.

\section{Appendix A}

Table A1. Results of the exercise with the stakeholders' answers to the following question: Which potential environmental tipping points would you identify on a regional scale? Each answer was written on a piece of paper and grouped by stakeholders into related topics. The names of the topics are in bold. Answers that were not tipping points were put aside and grouped either as drivers or consequences of tipping points or management measures. These are shown at the end of the table.

\begin{tabular}{|c|c|c|}
\hline Jordan & Palestine & Israel \\
\hline \multicolumn{3}{|c|}{ TIPPING POINTS NAMED DURING THE EXERCISE } \\
\hline $\begin{array}{l}\text { Overexploitation of water: } \\
\text { - } \quad \text { Nonconventional water use } \\
\text { - } \quad \text { Over extraction of groundwater } \\
\text { - } \quad \text { Over abstraction of freshwater } \\
\text { - } \quad \text { Groundwater salinity } \\
\text { - } \quad \text { Lowering of groundwater table } \\
\text { - } \quad \text { River water division } \\
\text { - } \quad \text { Desalination }\end{array}$ & $\begin{array}{l}\text { Deterioration of water quantity: } \\
\text { - } \quad \text { Drought due to rainfall } \\
\text { fluctuations and rising temp. } \\
\text { - } \quad \text { Water shortage } \\
\text { - } \quad \text { Decrease in water availability and } \\
\text { access to water (occupation) } \\
\text { - } \quad \text { Lowering of groundwater table } \\
\text { Extreme climatic events, } \\
\text { e.g., droughts }\end{array}$ & $\begin{array}{l}\text { Decline of water supply: } \\
\text { - } \quad \text { Depletion of coastal aquifer } \\
\text { - } \quad \text { Impacts on agriculture of } \\
\text { water supply decline }\end{array}$ \\
\hline $\begin{array}{l}\text { Desertification of rangeland: } \\
\text { - } \quad \text { Overgrazing, deterioration of } \\
\text { vegetation cover } \\
\text { - } \quad \text { Rangeland-loss of } \\
\text { biomass productivity } \\
\text { - } \quad \text { Land degradation } \\
\text { - } \quad \text { Unsustainable practices in tourism } \\
\text { - } \quad \text { Extreme climatic events, droughts } \\
\text { - } \quad \text { Fires and habitat loss }\end{array}$ & $\begin{array}{l}\text { Desertification and degradation of } \\
\text { rangeland: } \\
\text { - } \quad \text { Decline of rangeland productivity } \\
\text { - } \quad \text { Rangeland management } \\
\text { (overgrazing) } \\
\text { - } \quad \text { Desertification } \\
\text { - } \quad \text { Soil degradation } \\
\text { - } \quad \text { Loss of soil fertility }\end{array}$ & $\begin{array}{l}\text { Under-/over-grazing: } \\
\text { - } \quad \begin{array}{l}\text { Overgrazing interacting with } \\
\text { climate change }\end{array} \\
\text { - } \quad \begin{array}{l}\text { Highly resilient middle } \\
\text { eastern rangeland }\end{array} \\
\text { - } \quad \text { Lack of grazing }\end{array}$ \\
\hline $\begin{array}{l}\text { Deterioration of soil and food quality, } \\
\text { unsustainable agriculture: } \\
\text { - } \quad \text { Monocultivation } \\
\text { - } \quad \text { Agricultural management: } \\
\text { biodiversity loss, land conversion } \\
\text { - } \quad \text { Uncontrolled use of herbicides, } \\
\text { pesticides and fertilizers } \\
\text { - } \quad \text { Food security and quality } \\
\text { - } \quad \text { Livelihood index }\end{array}$ & 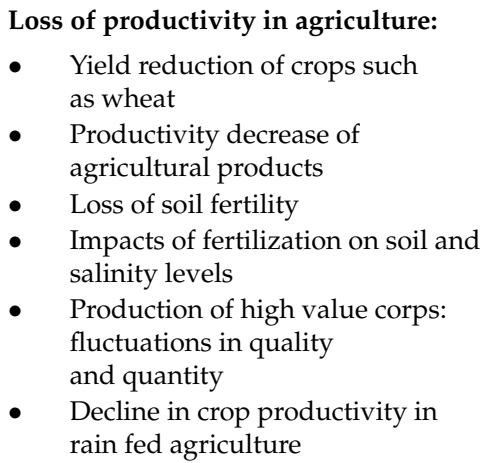 & $\begin{array}{l}\text { Agriculture-nature feedback: } \\
\text { - } \quad \text { Habitat loss due to } \\
\text { agriculture (land conversion) } \\
\text { - } \quad \begin{array}{l}\text { Agricultural impact on } \\
\text { natural systems and } \\
\text { vice versa }\end{array}\end{array}$ \\
\hline
\end{tabular}


Table A1. Cont.

\begin{tabular}{|c|c|c|}
\hline Jordan & Palestine & Israel \\
\hline \multicolumn{3}{|c|}{ TIPPING POINTS NAMED DURING THE EXERCISE } \\
\hline $\begin{array}{l}\text { Extinction of key species such as } \\
\text { tamarix, acacia: } \\
\text { - } \quad \text { Introduction of exotic plant species } \\
\text { that threaten native species } \\
\text { - } \quad \text { Loss of biodiversity, with diverse } \\
\text { impact on species, fauna, flora } \\
\text { - } \quad \text { Uncontrolled hunting } \\
\text { - } \quad \text { Ecosystem degradation due to } \\
\text { nonnative species }\end{array}$ & $\begin{array}{l}\text { Key species extinction: } \\
\text { - } \quad \text { Global bird migration: routes } \\
\text { under pressure } \\
\text { - } \quad \text { Local bird species threatened } \\
\text { - } \quad \text { Marine degradation (Gaza) } \\
\text { - } \quad \text { Loss of genetic resources (birds } \\
\text { - } \quad \text { Keyd plant species) } \\
\text { - } \quad \text { Wildiver threat } \\
\text { and natural pressure }\end{array}$ & $\begin{array}{l}\text { Key species extinction: } \\
\text { - } \quad \begin{array}{l}\text { Apex predators-trophic } \\
\text { cascades dysfunction }\end{array} \\
\text { - } \quad \text { Sharp decline of flag species, } \\
\text { e.g., vultures } \\
\text { - } \quad \text { Loss of pollinators } \\
\text { - } \quad \text { Poaching } \\
\text { - } \quad \text { Species extinction + grazing }\end{array}$ \\
\hline $\begin{array}{l}\text { Ecosystem degradation due to } \\
\text { non-native species: } \\
\text { - } \quad \text { Extinction of key land species } \\
\text { - } \quad \text { Loss of key species: tamarix, } \\
\text { acacia, ziziphus }\end{array}$ & $\begin{array}{l}\text { Erosion of values: } \\
\text { - } \quad \text { Animal rights and welfare (lack of } \\
\text { awareness on relationship } \\
\text { animals-humans, wildlife and } \\
\text { domestic life) } \\
\text { - Human behavior vis-à-vis } \\
\text { ecosystem services }\end{array}$ & $\begin{array}{l}\text { Alien species: } \\
\text { - Alien species } \\
\text { deliberate/undeliberate } \\
\text { threat to endemic species }\end{array}$ \\
\hline $\begin{array}{l}\text { Extinction of globally important } \\
\text { species: } \\
\text { - Uncontrolled hunting } \\
\text { - Loss of biodiversity, with diverse } \\
\text { impacts on species, fauna, flora }\end{array}$ & $\begin{array}{l}\text { Deterioration of water quality: } \\
\text { - } \quad \text { Intensive use of agrochemicals } \\
\text { - } \quad \text { Salinization of groundwater, } \\
\text { manmade (Gaza) and natural } \\
\text { (Jordan Valley) } \\
\text { - } \quad \text { Contamination and pollution }\end{array}$ & $\begin{array}{l}\text { Pollution: } \\
\text { - } \quad \text { Sewage } \\
\text { - } \quad \text { Accidents and disasters, e.g., } \\
\text { oil spill in Evrona } \\
\text { nature reserve } \\
\text { Pollution of wetlands and } \\
\text { terrestrial habitats }\end{array}$ \\
\hline \multirow[t]{2}{*}{ Marine coral acidification } & Dead Sea degradation & Shift in bioregions \\
\hline & & $\begin{array}{l}\text { Fires: } \\
\text { - Fire regime (natural } \\
\quad \text { and manmade) }\end{array}$ \\
\hline \multicolumn{3}{|c|}{ TIPPING POINTS OTHER THAN THOSE NAMED DURING THE EXERCISE } \\
\hline $\begin{array}{l}\text { Drivers } \\
\text { - } \quad \text { Urbanization } \\
\text { - } \quad \begin{array}{l}\text { Migration from rural to } \\
\text { urban areas }\end{array} \\
\text { - Fragmentation and/or loss of } \\
\text { forest areas } \\
\text { - } \quad \text { Fires and habitat loss } \\
\text { - } \quad \text { Drastic policy changes, e.g., } \\
\text { preventing further agriculture } \\
\text { Decline in annual precipitations, } \\
\text { combined with rising temperatures }\end{array}$ & 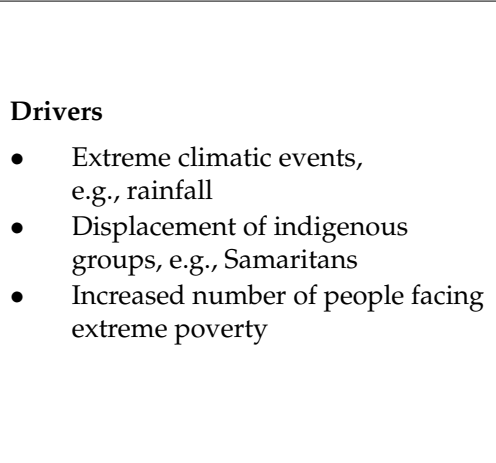 & $\begin{array}{l}\text { Drivers } \\
\text { - } \quad \text { Habitat loss due to } \\
\text { construction and } \\
\text { infrastructure development } \\
\text { - } \quad \text { Adverse planning decisions } \\
\text { by authorities } \\
\text { - } \quad \text { Climate index forecast } \\
\text { (precipitation) } \\
\text { - Climate index forecast } \\
\text { (heatwaves: duration and } \\
\text { temperature as } \\
\text { tipping points) } \\
\text { Extreme climatic events }\end{array}$ \\
\hline
\end{tabular}

\section{Consequences}

- Social and societal impacts

(income generation, unemployment, poverty, health)

- Competition over natural resources (gaps between investors, decision-makers and technical experts)

- Potential conflicts between end-users

\section{Consequences}

- Displacement, internal migration and urbanization

\section{Management measures}

- Rangeland rehabilitation

- Reforestation with native species

\section{Management measures}

- Ecologically friendly agriculture (reduces pesticide use) 


\section{References}

1. Grove, J.M.; Chowdhury, R.R.; Childers, D. Co-design, co-production, and dissemination of social-ecological knowledge to promote sustainability and resilience: Urban experiences from the US. Glob. Land Proj. News. 2015, 11, 6-11.

2. Reed, M.S.; Dougill, A.J.; Baker, T.R. Participatory indicator development: What can ecologists and local communities learn from each other. Ecol. Appl. 2008, 18, 1253-1269. [CrossRef] [PubMed]

3. Richards, C.; Carter, C.; Sherlock, K. Practical approaches to participation. In SERG Policy Brief No. 1; Carter, C.E., Spash, C.E., Eds.; Macaulay Institute: Aberdeen, UK, 2004. Available online: http:/ / macaulay. webarchive.hutton.ac.uk/ruralsustainability/SERG\%20PB1\%20final.pdf (accessed on 20 September 2018).

4. Stringer, L.C.; Dougill, A.J.; Fraser, E.; Hubacek, K.; Prell, C.; Reed, M.S. Unpacking "participation" in the adaptive management of social-ecological systems: a critical review. Ecol. Soc. 2006, 11, 39. Available online: http:/ / www.ecologyandsociety.org/vol11/iss2/art39/ (accessed on 10 September 2018). [CrossRef]

5. Gramberger, M.; Zellmer, K.; Kok, K.; Metzger, M. Stakeholder integrated research (STIR): A new approach tested in climate change adaptation research. Clim. Chan. 2015, 128, 201-214. [CrossRef]

6. Dakos, V.; Bascompte, J. Critical slowing down as early warning for the onset of collapse in mutualistic communities. Proc. Natl. Acad. Sci. USA 2014, 111, 17546-17551. [CrossRef] [PubMed]

7. Milkoreit, M.; Hodbod, J.; Baggio, J.; Benessaiah, K.; Calderón-Contreras, R.; Donges, J.F.; Mathias, J.D.; Rocha, J.C.; Schoon, M.; Werners, S.E. Defining tipping points for social-ecological systems scholarship-An interdisciplinary literature review. Environ. Res. Lett. 2018, 13, 033005. [CrossRef]

8. Scheffer, M.; Carpenter, S.; Foley, J.A.; Folke, C.; Walker, B. Catastrophic shifts in ecosystems. Nature 2001, 413, 591-596. [CrossRef] [PubMed]

9. Scheffer, M.; Carpenter, S.R.; Cline, T.J.; Pace, M.L. Anticipating critical transitions. Science 2012, 338, 344-348. [CrossRef] [PubMed]

10. Ben Dor, T.; Scheffran, J.; Hannon, B. Ecological and economic sustainability in fishery management: A multi-agent model for understanding competition and cooperation. Ecol. Econ. 2009, 68, 1061-1073. [CrossRef]

11. Kopp, R.E.; Shwom, R.L.; Wagner, G.; Yuan, J. Tipping elements and climate-economic shocks: Pathways toward integrated assessment. Earth's Future 2016, 4, 346-372. [CrossRef]

12. Henderson, K.A.; Reis, M.; Blanco, C.C.; Pillar, V.D.; Printes, R.C.; Bauch, C.T.; Anand, M. Landowner perceptions of the value of natural forest and natural grasslands in a mosaic ecosystem in southern Brazil. Sustain. Sci. 2016, 11, 321-330. [CrossRef] [PubMed]

13. Wang, R.; Dearing, J.A.; Langdon, P.G.; Zhang, E.; Yang, X.; Dakos, V.; Scheffer, M. Flickering gives early warning signals of a critical transition to a eutrophic lake state. Nature 2012, 492, 419-422. [CrossRef] [PubMed]

14. Liu, J.; Dietz, T.; Carpenter, S.R.; Alberti, M.; Folke, C.; Moran, E.; Pell, A.N.; Deadman, P.; Kratz, T.; Lubchenco, J.; Ostrom, E. Complexity of coupled human and natural systems. Science 2007, 317, 1513-1516. [CrossRef] [PubMed]

15. Browning, D.M.; Rango, A.; Karl, J.W.; Laney, C.M.; Vivoni, E.R.; Tweedie, C.E. Emerging technological and cultural shifts advancing drylands research and management. Front. Ecol. Environ. 2015, 13, 52-60. [CrossRef]

16. Innes, C.; Anand, M.; Bauch, C.T. The impact of human-environment interactions on the stability of forest-grassland mosaic ecosystems. Sci. Rep. UK 2013, 3, 1-10. [CrossRef] [PubMed]

17. Wall, D. The Commons in History. Culture, Conflict, and Ecology; MIT Press: Cambridge, MA, USA, 2014.

18. Ide, T.; Fröhlich, C. Socio-environmental cooperation and conflict? A discursive understanding and its application to the case of Israel and Palestine. Earth Syst. Dyn. 2015, 6, 659-671. [CrossRef]

19. Fung, T.; Seymour, R.M.; Johnson, C.R. Warning signals of regime shifts as intrinsic properties of endogenous dynamics. Am. Nat. 2013, 182, 208-222. [CrossRef] [PubMed]

20. Pimm, S.L. The complexity and stability of ecosystems. Nature 1984, 307, 321-326. [CrossRef]

21. Landi, P.; Minoarivelo, H.O.; Brännström, A.; Hui, C.; Dieckmann, U. Complexity and stability of ecological networks: A review of the theory. Popul. Ecol. 2018, 60, 1-27. [CrossRef]

22. Scheffran, J.; Hannon, B. From complex conflicts to stable cooperation. Complexity 2007, 13, 78-91. [CrossRef] 
23. Groffman, P.M.; Baron, J.S.; Blett, T.; Gold, A.J.; Goodman, I.; Gunderson, L.H.; Levinson, B.M.; Palmer, M.A.; Paerl, H.W.; Peterson, G.D.; Poff, N.L. Ecological thresholds: The key to successful environmental management or an important concept with no practical application? Ecosystems 2006, 9, 1-13. [CrossRef]

24. Barrett, S.; Dannenberg, A. Climate negotiations under scientific uncertainty. Proc. Natl. Acad. Sci. USA 2012, 109, 17372-17376. [CrossRef] [PubMed]

25. Scheffran, J.; Ide, T.; Schilling, J. Violent climate or climate of violence? Concepts and relations with focus on Kenya and Sudan. Int. J. Hum. Rights 2014, 18, 369-390. [CrossRef]

26. Eriksson, M.G.; Gordon, L.J.; Kuylenstierna, J. Cross-sectoral approaches help build water resilience-Reflections. Aquat. Procedia 2014, 2, 42-47. [CrossRef]

27. Horan, R.D.; Fenichel, E.P.; Drury, K.L.S.; Lodge, D.M. Managing ecological thresholds in coupled environmental-human systems. Proc. Natl. Acad. Sci. USA 2011, 108, 7333-7338. [CrossRef] [PubMed]

28. Jahn, T.; Bergmann, M.; Keil, F. Transdisciplinarity: Between mainstreaming and marginalization. Ecol. Econ. 2012, 79, 1-10. [CrossRef]

29. Lang, D.J.; Wiek, A.; Bergmann, M.; Stauffacher, M.; Martens, P.; Moll, P.; Swilling, M.; Thomas, C.J. Transdisciplinary research in sustainability science: Practice, principles, and challenges. Sustain. Sci. 2012, 7, 25-43. [CrossRef]

30. Brondizio, E.S.; O’Brien, K.; Bai, X.; Biermann, F.; Steffen, W.; Berkhout, F.; Cudennec, C.; Lemos, M.C.; Wolfe, A.; Palma-Oliveira, J.; Chen, C.T.A. Re-conceptualizing the Anthropocene: A call for collaboration. Glob. Environ. Chang. 2016, 39, 318-327. [CrossRef]

31. Lubchenco, J.; Petes, L.E. The interconnected biosphere: Science at the ocean's tipping points. Oceanography 2010, 23, 115-129. [CrossRef]

32. Sala, O.E.; Yahdjian, L.; Havstad, K.; Aguiar, M.R. Rangeland Ecosystem Services: Nature's Supply and Humans' Demand. In Rangeland Systems: Processes, Management and Challenges. Springer Series on Environmental Management; Briske, D.D., Ed.; Springer: Cham, Switzerland, 2017; pp. 467-489.

33. Joyce, L.A.; Marshall, N.A. Managing Climate Change Risks in Rangeland Systems. In Rangeland Systems: Processes, Management and Challenges. Springer Series on Environmental Management; Briske, D.D., Ed.; Springer: Cham, Switzerland, 2017; pp. 490-526.

34. Tielbörger, K.; Claus, C.; Schloz, D. (Eds.) GLOWA Jordan River: An Integrated Approach to Sustainable Management of Water Resources Under Global Change, Phase III. Final Report 2013. Available online: http:/ / dx.doi.org/10.2314/GBV:791521338 (accessed on 30 June 2018).

35. Myers, N.; Mittermeier, R.A.; Mittermeier, C.G.; da Fonseca, G.A.B.; Kent, J. Biodiversity hotspots for conservation priorities. Nature 2000, 4013, 853-858. [CrossRef] [PubMed]

36. Kuijt, I.; Finlayson, B. Evidence for food storage and predomestication granaries 11,000 years ago in the Jordan Valley. Proc. Natl. Acad. Sci. USA 2009, 106, 10966-10970. [CrossRef] [PubMed]

37. Claus, C.; Schloz, D.; Tielbörger, K. (Eds.) Concept Development for the Regional Centre for Transboundary Resource Management in the Jordan River Region. Final Report 2014. Available online: http:/ / doi.org/10. 2314/GBV:861261801 (accessed on 7 July 2018).

38. Fröhlich, C. Wasser-Konfliktstoff oder Kooperationsgrund? Der Fall des Nahen und Mittleren Ostens. In Wettstreit um Ressourcen. Konflikte um Klima, Wasser und Boden; Schneckener, U., von Scheliha, A., Lienkamp, A., Klagge, B., Eds.; oekom: München, Germany, 2014; pp. 181-217.

39. Samuels, R.; Smiatek, G.; Krichak, S.; Kunstmann, H.; Alpert, P. Extreme value indicators in highly resolved climate change simulations for the Jordan River area. J. Geophys. Res. 2011, 116, D24123.

40. Smiatek, G.; Kunstmann, H.; Heckl, A. High resolution climate change simulations for the Jordan River area. J. Geophys. Res. Atmos. 2011, 116, D16111. [CrossRef]

41. Törnros, T.; Menzel, L. Addressing drought conditions under current and future climates in the Jordan River region. Hydrol. Earth Syst. Sci. 2014, 18, 305-318. [CrossRef]

42. Bunce, R.G.H.; Metzger, M.J.; Jongman, R.H.G.; Brandt, J.; de Blust, G.; Elena-Rossello, R.; Groom, G.B.; Halada, L.; Hofer, G.; Howard, D.C.; et al. A standardized procedure for surveillance and monitoring European habitats and provision of spatial data. Landsc. Ecol. 2008, 23, 11-25. [CrossRef] 
43. Hoffmann, A.; Penner, J.; Vohland, K.; Cramer, W.; Doubleday, R.; Henle, K.; Kõljalg, U.; Kühn, I.; Kunin, W.E.; Negro, J.J.; et al. Improved access to integrated biodiversity data for science, practice, and policy-The European Biodiversity Observation Network (EU BON). Nat. Conserv. 2014, 6, 49-65. [CrossRef]

44. Cooke, B. The social psychological limits of participation. In Participation: The New Tyranny? Cooke, B., Kothari, U., Eds.; Zed Books: London, UK, 2001; pp. 102-121. 